\title{
NMDA But Not Non-NMDA Excitotoxicity is Mediated by Poly(ADP- Ribose) Polymerase
}

\author{
Allen S. Mandir, ${ }^{1}$ Marc F. Poitras, ${ }^{1}$ Adam R. Berliner, ${ }^{1}$ William J. Herring, ${ }^{1}$ Daniel B. Guastella, ${ }^{1}$ \\ Alicia Feldman, ${ }^{1}$ Guy G. Poirier, ${ }^{5}$ Zhao-Qi Wang, ${ }^{4}$ Ted M. Dawson, ${ }^{1,2}$ and Valina L. Dawson ${ }^{1,2,3}$
}

Departments of ${ }^{1}$ Neurology, ${ }^{2}$ Neuroscience, and ${ }^{3}$ Physiology, Johns Hopkins University School of Medicine, Baltimore, Maryland 21287, ${ }^{4}$ Department of Biochemistry and Molecular Biology, International Agency for Research on Cancer, Unit of Gene Environment Interactions, Lyon Cedex, France F69372, and 5 Unité de Recherche Santé et Environnement, Centre de Recherche du Centre Hospitalier de l'Université Laval and Faculté de Médecine, Université Laval, Sainte-Foy, Québec, Canada G1K 7P4

Poly(ADP-ribose) polymerase (PARP-1), a nuclear enzyme that facilitates DNA repair, may be instrumental in acute neuronal cell death in a variety of insults including, cerebral ischemia, 1-methyl-4-phenyl-1,2,3,6-tetrahydropyridine-induced parkinsonism, and CNS trauma. Excitotoxicity is thought to underlie these and other toxic models of neuronal death. Different glutamate agonists may trigger different downstream pathways toward neurotoxicity. We examine the role of PARP-1 in NMDA- and nonNMDA-mediated excitotoxicity. NMDA and non-NMDA agonists were stereotactically delivered into the striatum of mice lacking PARP-1 and control mice in acute (48 hr) and chronic (3 week) toxicity paradigms. Mice lacking PARP-1 are highly resistant to the excitoxicity induced by NMDA but are as equally susceptible to AMPA excitotoxicity as wild-type mice. Restoring PARP-1 protein in mice lacking PARP-1 by viral transfection restored susceptibility to NMDA, supporting the requirement of PARP-1 in NMDA neurotoxicity. Furthermore, Western blot analyses demonstrate that PARP-1 is activated after NMDA delivery but not after AMPA administration. Consistent with the theory that nitric oxide (NO) and peroxynitrite are prominent in NMDA-induced neurotoxicity, PARP-1 was not activated in mice lacking the gene for neuronal NO synthase after NMDA administration. These results suggest a selective role of PARP-1 in glutamate excitoxicity, and strategies of inhibiting PARP-1 in NMDA-mediated neurotoxicity may offer substantial acute and chronic neuroprotection.

Key words: AMPA; excitotoxicity; nitric oxide; NMDA; NOS; parkinsonism; PARP; poly(ADP-ribose); Sindbis virus
Poly(ADP-ribose) polymerase (PARP-1) is a nuclear enzyme that is activated primarily by DNA damage. Upon activation, the enzyme hydrolyzes nicotinamide adenine dinucleotide (NAD) to nicotinamide and transfers ADP ribose units to a variety of nuclear proteins, including histones and PARP-1 itself (de Murcia et al., 1994; D'Amours et al., 1999). This process is important in facilitating DNA repair. However, excessive activation of PARP-1 can lead to significant decrements in NAD and ATP depletion, which leads to cell death (Berger, 1985; Zhang et al., 1994; Eliasson et al., 1997; Endres et al., 1997). Excessive PARP-1 activation is implicated in a variety of insults, including cerebral ischemia, 1-methyl4-phenyl-1,2,3,6-tetrahydropyridine (MPTP)-induced parkinsonism, traumatic spinal cord injury, and streptozotocin-induced diabetes (Eliasson et al., 1997; Endres et al., 1997; Burkart et al., 1999; Mandir et al., 1999; Masutani et al., 1999; Pieper et al., 1999; Scott et al., 1999).

Excitotoxicity is thought to play a prominent role in a variety of acute and chronic neurological injuries from the excessive activa-

\footnotetext{
Received April 17, 2000; revised Aug. 18, 2000; accepted Aug. 22, 2000.

A.S.M. is supported by United States Public Health Service/Clinical Investigator Development Award Grant NS 1K08NS02035-01 and a National Parkinson's Foundation Research grant. M.F.P is supported by the Canadian Heart and Stroke Foundation and Le Fonds pour la Formation de Chercheurs et l'Aide à la Recherche. G.G.P. is supported by the Medical Research Council of Canada. W.J.H is supported by United States Public Health Service/Clinical Investigator Development Award Grant NS 1K08NS02024. V.L.D. is supported by United States Public Health Service Grant NS39148, the American Heart Association, and the Amyotrophic Lateral Sclerosis Association and is a National Alliance for Research on Schizophrenia and Depression Staglin Music Festival Investigator. T.M.D. is an Established Investigator of the American Heart Association and is supported by United States Public Health Service Grant NS39148 and the Mitchell Foundation. We thank Ann Schmidt for secretarial assistance. We thank Dr. Richard L. Huganir for his kind donation of GluR1 and GluR2/3 antibodies.

Correspondence should be addressed to Dr. Valina L. Dawson, Johns Hopkins University School of Medicine, Department of Neurology, 600 N. Wolfe Street, Carnegie 214, Baltimore, MD 21287. E-mail: vdawson@jhmi.edu.

Copyright (C) 2000 Society for Neuroscience $0270-6474 / 00 / 208005-07 \$ 15.00 / 0$
}

tion of the excitatory neurotransmitter glutamate acting on NMDA receptors (NMDA-R) and non-NMDA-R (Choi, 1988; Meldrum and Garthwaite, 1990; Olney, 1990; Lipton and Rosenberg, 1994). A number of studies demonstrate a prominent role for nitric oxide (NO) in excitotoxicity in vivo and in vitro (V. L. Dawson et al., 1991, 1993; T. M. Dawson et al., 1993; Huang et al., 1994; Lynch and Dawson, 1994; Schulz et al., 1995a,b; Iadecola, 1997; Leist and Nicotera, 1998). Primary brain cultures treated with NO synthase (NOS) inhibitors or cultures from mice with targeted disruption of neuronal NOS (nNOS) are resistant to NMDA neurotoxicity (V. L. Dawson et al., 1991, 1993; T. M. Dawson et al., 1993). nNOS knock-out mice are also resistant to neuronal damage after middle cerebral artery occlusion and intrastriatal NMDA excitotoxic lesions but not AMPA excitotoxicity (Huang et al., 1994; Ayata et al., 1997). NO is thought to mediate the majority of its toxic effects through the interaction with the superoxide anion to form the potently toxic oxidant peroxynitrite (Dawson et al., 1991; Beckman and Crow, 1993; Dawson and Dawson, 1996; Xia et al., 1996). Peroxynitrite and NO damage DNA, the presence of which is a prime activator of PARP-1. PARP-1 plays a key role in NMDAand NO-induced neurotoxicity because mice lacking the gene for PARP-1 or cultures treated with PARP-1 inhibitors are resistant to the toxic effects of these agents (Zhang et al., 1994; Eliasson et al., 1997; Endres et al., 1997). The role of PARP-1 in excitotoxicity in vivo is not known, and more specifically, the contributions of PARP-1 to NMDA- versus non-NMDA-mediated neuronal damage have not been explored. In this study, we demonstrate that NMDA excitotoxicity is dramatically reduced in PARP-1 knockout mice, whereas PARP-1 knock-out mice are sensitive to AMPA excitotoxicity.

\section{MATERIALS AND METHODS}

Mice. All experiments were approved and conformed to the guidelines set by the Institutional Animal Care Committee. To avoid differences caused from strain effect or divergent genetic lines, PARP-1 knock-out (PARP- 
$1^{-/-}$) mice used in this study were on a pure $129 \mathrm{~Sv} / \mathrm{Ev}$ background (Wang et al., 1997) with the colony maintained by outbreeding with purebred 129 Sv/Ev wild-type (WT) controls (Taconic, Germantown, NY). Thus, the PARP $-1^{-1-}$ mice are of the same strain as controls, and inbreeding effects are minimized. Mice were $20-28 \mathrm{gm}$ and male. The $\mathrm{nNOS}^{-1-}$ mice were maintained on a C57/BL6 background and were male, weighing 20-25 gm.

Intrastriatal microinjections. Spontaneously breathing mice were anesthetized with pentobarbital $(45 \mathrm{mg} / \mathrm{kg}$, i.p.), and the head was fixed in a stereotactic frame (Kopf, Tujunga, CA). A burr hole was drilled above the right striatum [rostral, $0.5 \mathrm{~mm}$; lateral, $1.7 \mathrm{~mm}$; ventral, $3.5 \mathrm{~mm}$ from bregma (Franklin and Paxinos, 1997)]. NMDA (66.7 mM), AMPA (20 $\mathrm{mM}$ ), or vehicle (0.1 M PBS, $\mathrm{pH} 7.4$ ) was injected over 2 min (volume of 0.3 $\mu \mathrm{l})$, and the needle was left in place for an additional $8 \mathrm{~min}$ after injection.

For viral transfection, $4-6 \mathrm{~d}$ before receiving vehicle or NMDA, Sindbis viral constructs expressing either LacZ or full-length PARP-1 WT protein were injected at $1.0 \mu \mathrm{l}$ volume over $20 \mathrm{~min}$ using a microinjector pump (World Precision Instruments, Sarasota, FL). The identical stereotactic coordinates were used as for toxin or vehicle delivery, and the needle was held in place for an additional $10 \mathrm{~min}$.

The mice were allowed to survive for $48 \mathrm{hr}$ for acute studies and for 3 weeks for chronic studies after toxin or vehicle delivery. The mice were deeply anesthetized with phenobarbital and then perfusion-fixed with

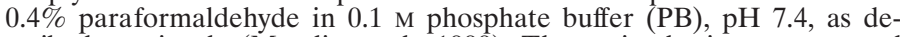
scribed previously (Mandir et al., 1999). The entire brain was removed after perfusion, post-fixed in the same fixative solution, and cryoprotected in $20 \%$ glycerol- $-0.1 \mathrm{M}$ PB for freezing and serial sectioning.

PARP-1 activity assay. Cells or nuclear pellets were resuspended in 400 $\mu l$ of PARP-1 assay media $\left(50 \mathrm{~mm}\right.$ Tris/ $\mathrm{HCl}, \mathrm{pH} 8,2.5 \mathrm{~mm} \mathrm{MgCl}_{2}, 1 \mathrm{~mm}$ DTT, and $100 \mu \mathrm{g} / \mathrm{ml}$ PMSF) and maintained on ice. The activation of PARP-1 was induced by sonication to induce DNA breaks for $6 \mathrm{sec}$ using a Branson Sonifier 250 at an intermediate setting, and samples were kept on ice for $1 \mathrm{~min}$. This procedure was then repeated once. Samples were brought to $25^{\circ} \mathrm{C}$, and $100 \mu \mathrm{l}$ of each was added to $100 \mu \mathrm{l}$ of PARP-1 assay media (pre-equilibrated at $25^{\circ} \mathrm{C}$ ) supplemented with $500 \mu \mathrm{M}$ NAD $(0.5-1.0$ $\mu \mathrm{Ci} / 100 \mu \mathrm{l}$ of $\left[{ }^{32} \mathrm{P}\right] \mathrm{NAD}$ ) and incubated for $10 \mathrm{~min}$ at $25^{\circ} \mathrm{C}$ (Shah et al., 1996). The reaction was stopped by $2 \mathrm{ml}$ of ice-cold TCA 20\%, and samples were incubated for $30 \mathrm{~min}$ on ice. Precipitated proteins were collected by filtration through $\mathrm{FC} / \mathrm{C}$ glass fiber filters (Whatman International Ltd., Maidstone, UK), and the filters were washed with $10 \mathrm{ml}$ of ethanol. The radioactivity incorporated into proteins and retained on the filter were evaluated by liquid scintillation counting, and results were expressed as picomoles of incorporated $\left[{ }^{32} \mathrm{P}\right] \mathrm{NAD}$ per $200 \mu \mathrm{g}$ of protein.

Viral constructs. Sindbis virus vectors were constructed in which LacZ and wild-type PARP-1 were subcloned into the pSINRep5 plasmid (Invitrogen, San Diego, CA) and linearized with XhoI, NotI, or PacI. The DNA was phenol-extracted, precipitated, and resuspended in RNase-free water. The linearized DNA was transcribed in vitro with the SP6 enzyme for $2 \mathrm{hr}$ at $37^{\circ} \mathrm{C}$. RNA was transfected into baby hamster kidney (BHK) cells by electroporation. BHK cells were trypsinized, washed, and resuspended in RNase-free PBS without cations. RNA $(10 \mu \mathrm{g})$ was added, and the cells were electroporated, recovered on ice for $5 \mathrm{~min}$ before plating in complete MEM, and incubated for 24-72 hr. The media was used to transfect BHK cells that were harvested after $2-3 \mathrm{~d}$, and the cells were pelleted by centrifugation. The pellet was freeze-thawed several times in $10 \mathrm{~mm}$ Tris, $\mathrm{pH} 8$, and $1 \mathrm{~mm} \mathrm{MgCl}_{2}$ and centrifuged. Supernatants were combined and filtered through a $0.2 \mu \mathrm{m}$ filter. The virus was amplified in BHK cells and purified over a sucrose gradient in which BHK cells were harvested after 2-3 d and centrifuged. A large-scale purification was performed by resuspending and combining the cell pellets in $50 \mathrm{~mm}$ Tris, $\mathrm{pH} 7.4,10 \mathrm{~mm} \mathrm{NaCl}$, and $0.5 \mathrm{~mm}$ EDTA and centrifuging at $1000 \times g$ at 15 min. The supernatant was transferred onto a two-part step gradient of sucrose $(20 \% / 55 \%)$ and spun at $30,000 \times g$ in a swinging bucket rotor (SW41) for $1 \mathrm{hr}$ at $14^{\circ} \mathrm{C}$. The media was removed, and the virus band was extracted from the $20 \% / 55 \%$ interface. The virus was aliquoted, frozen on dry ice, and stored at $-80^{\circ} \mathrm{C}$.

Lesion volume analysis. The frozen brains were sectioned through the entire striatum at $40 \mu \mathrm{m}$ intervals; each section was mounted on slides and stained with cresyl violet. Each section was imaged using a digital camera, and lesion areas and total intrastriatal lesion volume was determined for each animal. Lesions, defined as loss of cresyl violet staining in the injected striatum, were circumscribed by tracing on a computer (Loats, Westminster, MD)

Poly(ADP-ribose) polymer Western blots. Striata were dissected from mice at 2, 4, 8, 16, and $24 \mathrm{hr}$ after toxin or vehicle delivery and immediately frozen. Samples were homogenized in buffer $(10 \mathrm{~mm}$ Tris- $\mathrm{HCl}, \mathrm{pH} 8.0,2$ $\mathrm{mm} \mathrm{MgCl}_{2}, 2 \mathrm{~mm}$ DTT, $0.1 \mathrm{~mm}$ PMSF, $10 \mu \mathrm{g} / \mathrm{ml}$ leupeptin, $100 \mu \mathrm{g} / \mathrm{ml}$ benzamidine, and $0.25 \mathrm{~mm}$ sucrose) and centrifuged for $5 \mathrm{~min}$ at $14,000 \times$ $g$, and the pellet was resuspended in buffer. Protein concentrations were determined by the Bradford assay, and equal samples were loaded on a gradient SDS-PAGE gel $(80 \mu \mathrm{g} /$ lane $)$. For fibroblasts, cells were resuspended in $400 \mu \mathrm{l}$ of PARP-1 assay media and subjected to the procedure above. The gels were transferred to a nitrocellulose membrane and incubated with anti-poly(ADP-ribose) polyclonal antibody. Membranes were stained with Ponceau S (0.1\%) to confirm equal loading and transfer. After blocking of nonspecific sites, membranes were incubated with rabbit anti-poly(ADPribose) polyclonal antibody 96-10 to poly(ADP-ribose) (1:2000) (Affar et al., 1998, 1999). Bands were visualized by chemiluminescence.
Cortical cultures. Primary cortical cultures were prepared from gestational day 16 PARP-1 ${ }^{-1-}$ or WT mice as described previously (Dawson et al., 1996; Gonzalez-Zulueta et al., 1998). Briefly, the cortex was dissected, and the cells were dissociated by trituration in Eagle's medium (MEM), $20 \%$ horse serum, $25 \mathrm{~mm}$ glucose, and $2 \mathrm{~mm}$ L-glutamine after a $30 \mathrm{~min}$ digestion in $0.027 \%$ trypsin-saline solution (Life Technologies, Gaithersburg, MD). The cells were then plated on $15 \mathrm{~mm}$ multiwell plates coated with polyornithine. Four days after plating, the cells are treated with 5-fluoro-2-deoxyuridine for $3 \mathrm{~d}$ to inhibit proliferation of non-neuronal cells. Cells are then maintained in MEM, $10 \%$ horse serum, $25 \mathrm{~mm}$ glucose, and $2 \mathrm{~mm}$ L-glutamine in an $8 \% \mathrm{CO}$, humidified $37^{\circ} \mathrm{C}$ incubator. The growth medium was refreshed twice per week, and the neurons were allowed to mature for $14 \mathrm{~d}$ in culture before being used for experiments. For cytotoxicity experiments, the cells were prewashed with Tris-buffered control salt solution containing (in $\mathrm{mM}$ ): $120 \mathrm{NaCl}, 5.4 \mathrm{KCl}, 1.8 \mathrm{CaCl}_{2}, 25$ Tris- $\mathrm{HCl}, \mathrm{pH} \mathrm{7.4}$, and 15 glucose. The exposure solutions containing NMDA $(500 \mu \mathrm{M})$ or AMPA $(50 \mu \mathrm{M})$ alone or in the presence of DNQX or Earle's balanced salt solution were administered for $5 \mathrm{~min}$ and then washed off. The cells were then placed in growth medium and returned to the incubator overnight.

Toxicity was assayed $20-24 \mathrm{hr}$ after exposure by microscopic examination with computer-assisted cell counting after staining of all nuclei with 1 $\mu \mathrm{g} / \mathrm{ml}$ Hoescht 33342 stain and staining of dead cell nuclei with $7 \mu \mathrm{M}$ propidium iodide. Total and dead cells were counted. Glial nuclei fluoresce at a different intensity than neuronal nuclei and were gated out (GonzalezZulueta et al., 1998). Percent cell death was determined as the ratio of live-to-dead cells compared with the percent cell death in control wells to account for cell death attributable to mechanical stimulation of the cultures. At least two separate experiments using four separate wells were performed with a minimum of 8000-20,000 neurons counted per data point. All reagents were purchased from Sigma (St. Louis, MO) or Life Science Inc. (Boston, MA).

Glutamate receptor Western blots. Cortical cultures from PARP-1 ${ }^{-1-}$ and WT animals as described above were homogenized in buffer $(10 \mathrm{mM}$ Tris-HCl, pH 8.0, $2 \mathrm{~mm} \mathrm{MgCl}_{2}, 2 \mathrm{mM}$ DTT, $0.1 \mathrm{mM} \mathrm{PMSF}, 10 \mu \mathrm{g} / \mathrm{ml}$ leupeptin, $100 \mu \mathrm{g} / \mathrm{ml}$ benzamidine, and $0.25 \mathrm{~mm}$ sucrose) and centrif uged for $5 \mathrm{~min}$ at $14,000 \times \mathrm{g}$, and the pellet was resuspended in buffer. Protein concentrations were determined by the Bradford assay, and equal samples were loaded on a gradient SDS-PAGE gel $(30 \mu \mathrm{g} / \mathrm{lane})$. The gels were transferred to a nitrocellulose membrane and stained with Ponceau $\mathrm{S}$ $(0.1 \%)$ to confirm equal loading and transfer. Membranes were incubated with NMDA-R1 (1:10,000) (Weiss et al., 1998), glutamate receptor 1 (GluR-1) (1:500), or GluR-2/3 (1:500) polyclonal antibodies (GluR-1 and GluR-2/3 antibodies were generously donated from the laboratory of Dr. Richard L. Huganir, Johns Hopkins University, Baltimore, MD). Bands were visualized by chemiluminescence.

Statistical analysis. Values of lesion volume analysis are expressed as the mean \pm SD. Differences among means were analyzed using one-way ANOVA. When ANOVA demonstrated significant differences among the groups, pair-wise comparisons between means were tested by Fisher or Newman-Keuls post hoc tests using STATVIEW (Abacus Software, San Francisco, CA).

\section{RESULTS \\ NMDA and AMPA lesions in wild-type and PARP-1} knock-out mice

Previous studies indicate that intrastriatal microinjections of NMDA and AMPA produce maximal lesion volumes at $\sim 48 \mathrm{hr}$ (Ayata et al., 1997). As such, throughout the majority of our experiments, we analyzed lesion volumes $48 \mathrm{hr}$ after NMDA or AMPA injections. Both NMDA and AMPA consistently produced well delineated lesions (Fig. 1). Six nanomoles of AMPA consistently produce larger striatal lesion volumes than $20 \mathrm{nmol}$ of NMDA (Fig. 2). The lesions are typically located approximately at the level of bregma and for the most part are confined to the striatum. NMDA-induced lesions are barely perceptible in the PARP-1 $1^{-/}$mice (Figs. 1, 2A). In the majority of NMDA-injected PARP- $1^{-/-}$, mice only the needle track is detectable.

AMPA induced lesions in PARP-1 ${ }^{-1-}$ mice are not significantly different from AMPA lesions in wild-type mice; however, there is a trend toward being slightly larger lesions in the PARP-1 ${ }^{-/-}$mice (Figs. 1, 2B). To confirm the apparent lack of resistance to AMPA excitotoxicity in PARP-1 ${ }^{-/-}$mice, we examined AMPA excitotoxicity in cortical cultures. We find that PARP-1 $1^{-1-}$ cortical cultures are sensitive to AMPA, although a partial and significant protection is seen (Fig. 3). As shown previously, PARP-1 $1^{-/-}$cultures are markedly resistant to NMDA excitotoxicity (Fig. 3) (Eliasson et al., 1997). To address potential differences in amount of glutamate receptor expression between PARP- $1^{-/-}$and WT mice, Western blots of cortical cultures were probed with antibody toward 


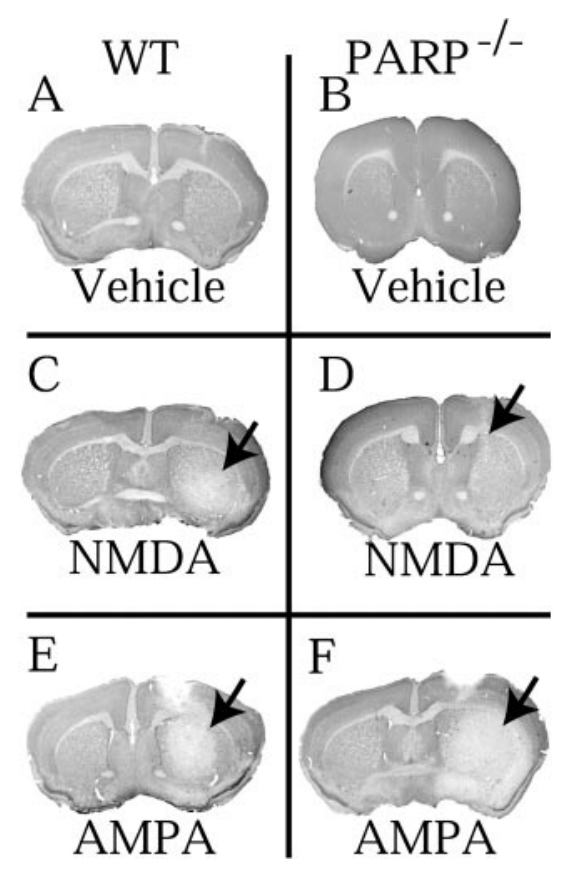

Figure 1. Representative coronal sections stained with cresyl violet to reveal lesions in WT $(A, C, E)$ and PARP-1 ${ }^{-/-}(B, D, F)$ mice 48 hr after treatment with NMDA, AMPA, or vehicle alone. PARP-1 ${ }^{-1-}$ mice demonstrate remarkable resistance to NMDA intrastriatal injections with lesion volumes similar to vehicle alone. Lesion volumes in PARP-1 ${ }^{-1}$ are not significantly different from WT mice receiving intrastriatal injections of AMPA.
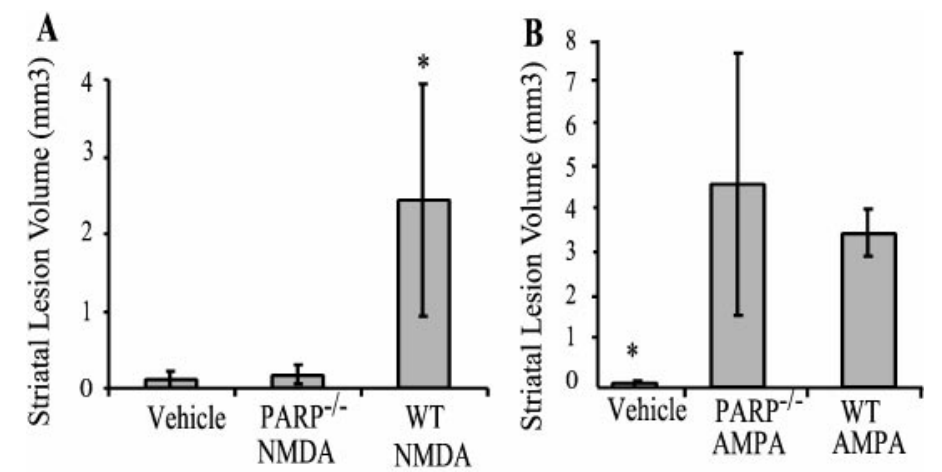

Figure 2. Average lesions volumes from WT and PARP-1 ${ }^{-/-}$mice $48 \mathrm{hr}$ after 20 nmol of NMDA $(A)(n=7)$ or 6 nmol of AMPA $(B)(n=6)$. Volumes are expressed as mean \pm SD. In $A$, asterisk indicates significant difference between PARP-1 $1^{-1-}$ and WT after NMDA injections $(p<0.5$ ANOVA). No statistical differences are observed between PARP-1 ${ }^{-1-}$ and WT animals receiving intrastriatal AMPA injections. In $B$, asterisk indicates both are significantly different than vehicle injection lesion volumes.

NMDA-R1, GluR-1, and GluR-2/3 (Fig. 3). Differences in neurotoxicity do not seem to result from different receptor expression levels. Western blot analysis of glutamate receptors on fresh frozen striata of PARP-1 ${ }^{-/-}$and WT mice also demonstrate equal amounts of receptors (data not shown).

\section{PARP-1 activation after excitotoxin microinjection}

We monitored poly(ADP-ribosyl)ation with a highly selective and specific antibody to poly(ADP-ribose). NMDA (20 nmol) potently activates PARP-1 within $2 \mathrm{hr}$ after the initial injection. NMDA activation of PARP-1 is maximal at $4 \mathrm{hr}$ and begins to taper off at $8 \mathrm{hr}$ but remains active for at least $24 \mathrm{hr}$ (Fig. $4 A$ ). No PARP-1 activation is detectable in PARP- $1^{-/-}$mice injected with NMDA, nor is PARP-1 activity detectable in saline-injected wild-type animals (Fig. 4). In contrast, AMPA (6 nmol) produces barely detectable PARP-1 activation as assessed at 2, 4, 8, and $24 \mathrm{hr}$ (Fig. 4B).
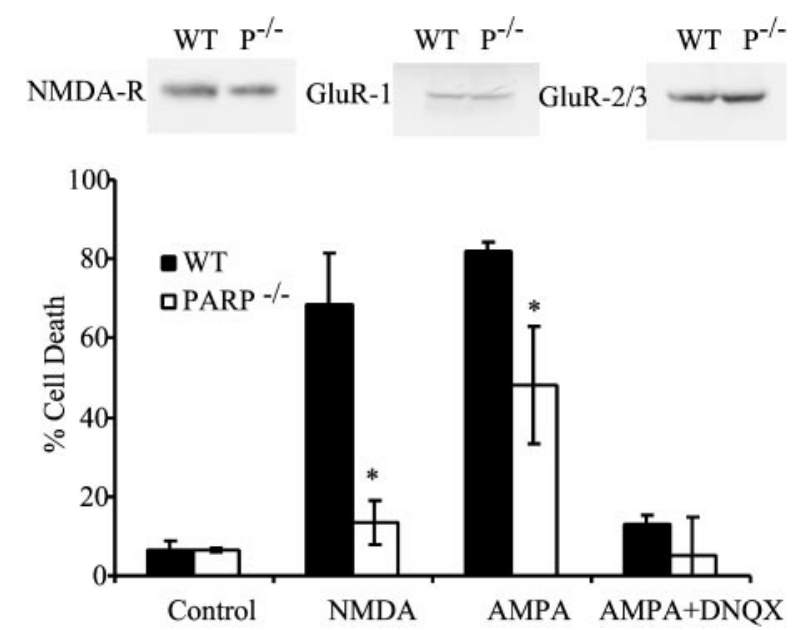

Figure 3. Cortical cultures from WT or PARP-1 ${ }^{-1-}\left(P^{-/-}\right)$express equal levels of NMDA-R, GluR1, and GluR2/3 as determined by Western blot analysis. The experiment was performed twice with similar results. Cortical cultures from WT or PARP-1 ${ }^{-1-}$ mice exposed to NMDA $(500 \mu \mathrm{M})$, vehicle alone, and AMPA $(50 \mu \mathrm{M})$ with or without the presence of the glutamate antagonist DNQX. PARP- $1^{-1-}$ or WT cultures exposed to AMPA alone demonstrate significant percentage of cell death compared with control or DNQX-treated cultures ( $p<0.01$; ANOVA; mean $\pm \mathrm{SD})$. Unlike the substantial protection exhibited by PARP-1 $1^{-1-}$ cultures to NMDA neurotoxicity compared with WT as shown previously (Eliasson et al., 1997), PARP-1 ${ }^{-/-}$cultures demonstrate a partial but significant percentage of protection to AMPA neurotoxicity in vitro $(* p<0.05$, WT compared with PARP knock-outs; significance determined by ANOVA with Newman-Keuls post hoc analysis). Experiments were replicated a minimum of two times with at least $8000-20,000$ neurons counted per experiment.

NO and peroxynitrite are thought to play a major role in activating PARP-1 through their ability to promote nonapoptotic DNA damage (Radons et al., 1994; Zhang et al., 1994, 1995). To determine whether there is a link between NO-peroxynitrite and PARP-1 activation in NMDA-induced excitotoxic injury, we monitored poly(ADP-ribosyl)ation after NMDA administration in mice lacking the gene for neuronal $\mathrm{NO}$ synthase $\left(\mathrm{nNOS}^{-/-}\right)$ (Huang et al., 1993). Remarkably, we detect minimal poly(ADPribose) formation in $\mathrm{nNOS}^{-1-}$ mice (Fig. 4C).

\section{Sustained protection against NMDA excitotoxicity in PARP-1 ${ }^{-1}$ mice}

To ascertain whether the neuroprotection observed in the PARP$1^{-1-}$ mice is long-lasting, we examined lesion volumes in PARP$1^{-/-}$mice versus wild-type mice 3 weeks after the intrastriatal NMDA microinjection (Fig. 5). At this chronic time point after NMDA intrastriatal microinjection, the lesion volume is $\sim 70 \%$ smaller in the PARP-1 $1^{-1-}$ mice than WT animals (Fig. 5).

\section{Characterization of PARP-1-containing viruses}

To demonstrate that the observed neuroprotection is attributable to the absence of the PARP-1 gene as opposed to developmental consequences or other potential genetic influences attributable to the lack of the PARP-1 gene, we developed a method of restoring PARP-1 activity in PARP-1 ${ }^{-1-}$ mice. We generated recombinant replication-deficient Sindbis viruses carrying the marker gene $\beta$-galactosidase (lacZ), and a wild-type PARP-1 virus (Fig. 6). We initially evaluated the Sindbis virus constructs in PARP-1 ${ }^{-1-}$ fibroblasts. Sindbis-containing wild-type PARP-1 exhibit significant PARP-1 activity in PARP-1 ${ }^{-1-}$ fibroblasts as ascertained by both $\left[{ }^{32} \mathrm{P}\right]$ NAD incorporation and Western blot analysis of ADP(ribosyl)ated proteins. Sindbis virus-containing lac $Z$ was essentially devoid of PARP-1 catalytic activity (Fig. 6).

\section{Intrastriatal microinjection of wild type PARP-1 virus restored NMDA excitotoxicity in PARP-1 ${ }^{-/-}$animals}

Intrastriatal microinjection of the Sindbis viruses leads to a significant incorporation of virus into the striatum (Fig. $7 A$ ). Of note is 
A
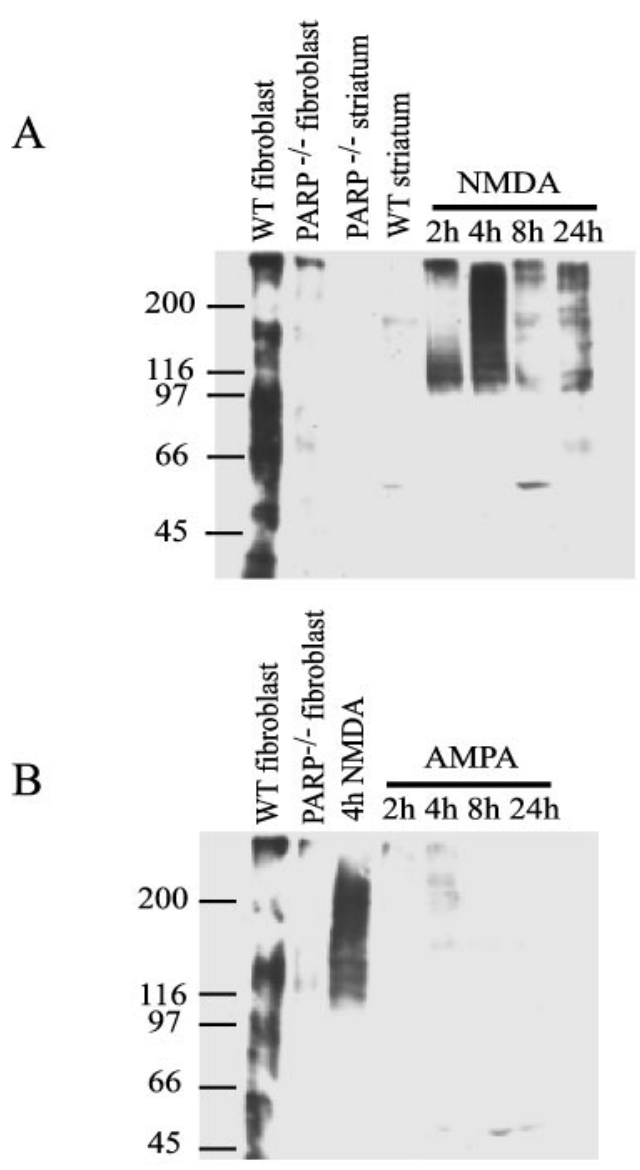

\section{$\mathrm{C}$}

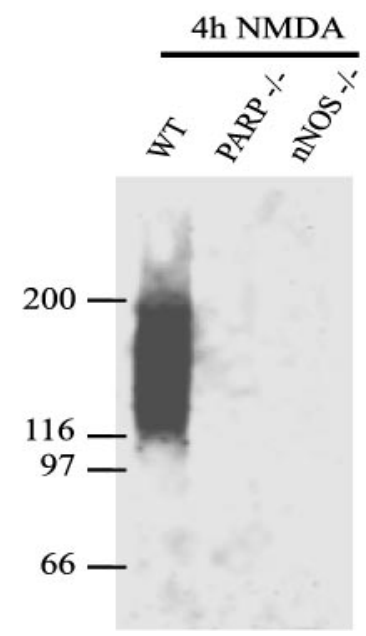

Figure 4. A, Western blots demonstrating the time course of PARP-1 activation after $20 \mathrm{nmol}$ of NMDA intrastriatal injections in WT mice. Striata from PARP-1 $1^{-/-}$or WT mice were prepared as described in Materials and Methods. PAR polymer formation is seen $2 \mathrm{hr}$ after injection with a peak detection of polymer at $4 \mathrm{hr}$ after injection. Sonicated fibroblasts incubated with NAD serve as the positive control. $B$, Time course of PARP-1 activation after $6 \mathrm{nmol}$ of AMPA intrastriatal injection in wildtype mice. Minimal PARP-1 activation is seen compared with NMDA injections (4 hr NMDA PAR formation shown for comparison). $C$, Although PARP-1 is activated maximally at $4 \mathrm{hr}$ after NMDA injection in WT mice, nNOS ${ }^{-1-}$ mice do not demonstrate PAR polymer formation after NMDA injection. These results were replicated three times with similar results.

that the virus has a propensity to track along the corpus callosum and remains concentrated within the needle track. However, significant expression is routinely observed several millimeters away from the needle track. Neurons are predominantly infected, be-

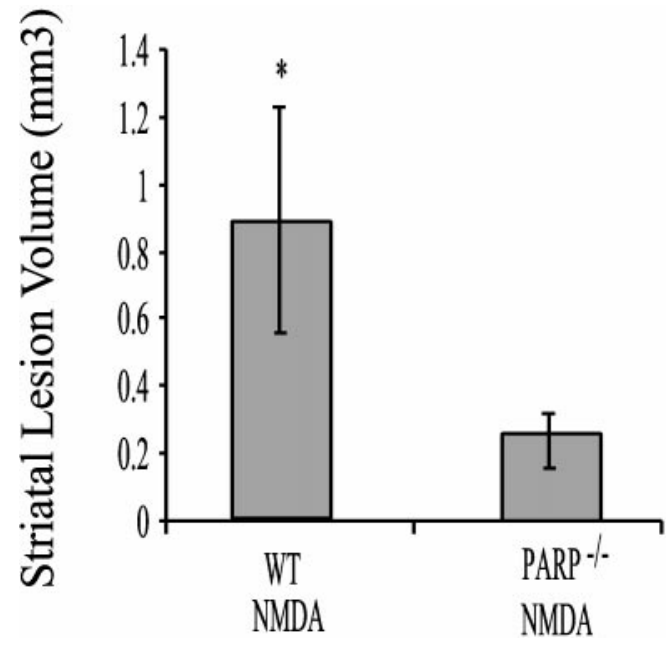

Figure 5. Histogram of mean intrastriatal volumes 3 weeks after NMDA injection in WT $(n=3)$ and PARP- $1^{-1-}(n=3)$ mice. PARP- $1^{-/-}$mice still demonstrate minimal lesion volume chronically after NMDA injection. WT mice demonstrate significantly greater lesion volumes than PARP-1 ${ }^{-1-}$ mice $\left({ }^{*} p<0.05\right.$; Student's $t$ test).

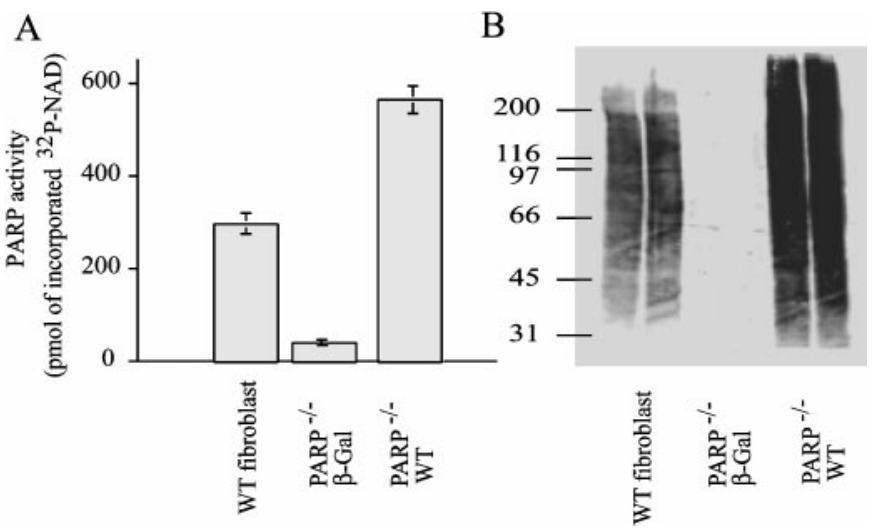

Figure 6. PARP-1 activity in WT and PARP-1 $1^{-/-}$fibroblast cells infected with Sindbis virus-containing cDNA encoding lac $Z$ or WT PARP-1. A, WT or PARP- $1^{-1-}$ fibroblasts infected with WT PARP-1 demonstrate prominent PARP-1 activation as quantified by amount of $\left[{ }^{32} \mathrm{P}\right] \mathrm{NAD}$ incorporated after sonication in the presence of [ $\left.{ }^{32} \mathrm{P}\right] N A D$. $B$, PAR polymer formation determined by Western blot indicates that wild-type PARP-1 Sindbis virus restores PARP-1 activity in PARP-1 ${ }^{-1-}$ fibroblasts. Data shown are representative of duplicate experiments.

cause Sindbis is a neurotrophic virus (Jackson et al., 1988; Dubuisson et al., 1997; Griffin, 1998). Forty-eight hours after NMDA or vehicle injection in the mice receiving the various Sindbis viruses, lesion volumes were ascertained (Fig. 7). Sindbis virus-containing wild-type PARP-1 significantly restores the susceptibility to NMDA excitotoxicity in PARP-1 $1^{-/-}$mice (Fig. 7). In contrast, the Sindbis virus-containing lac $Z$ did not restore susceptibility to NMDA excitotoxicity in PARP-1 ${ }^{-/-}$mice (Fig. 7).

\section{DISCUSSION}

We demonstrate a selective resistance of PARP-1 ${ }^{-/}$mice to NMDA versus non-NMDA glutamate-mediated excitotoxicity. Although PARP-1 ${ }^{-/-}$mice are dramatically resistant to NMDA receptor-mediated toxicity, they demonstrate equal sensitivity as wild-type mice to non-NMDA-mediated toxicity. This differential resistance to NMDA versus non-NMDA excitoxicity is observed in both in vivo and in vitro paradigms. We further demonstrate by Western blot analysis that NMDA preferentially activates PARP-1, whereas AMPA fails to significantly activate PARP-1. We fail to observe PARP-1 activation in mice lacking the gene for nNOS after treatment with NMDA, suggesting that NO production acti- 
A

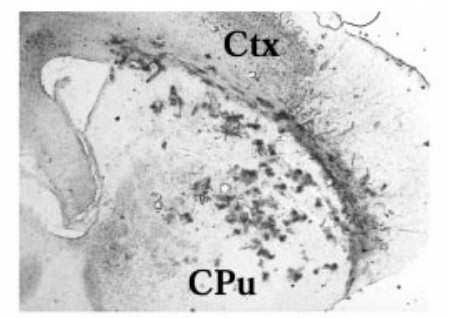

B

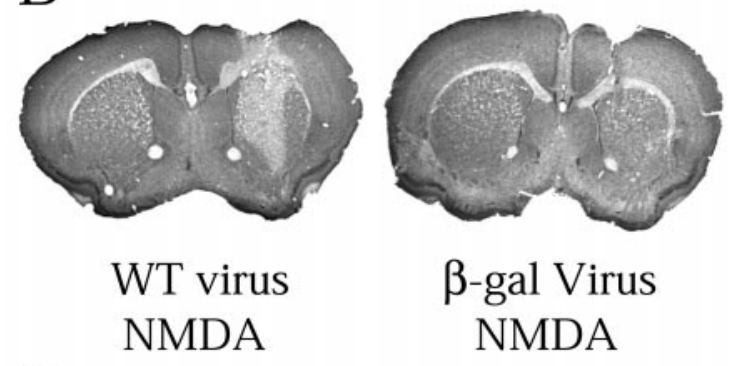

C

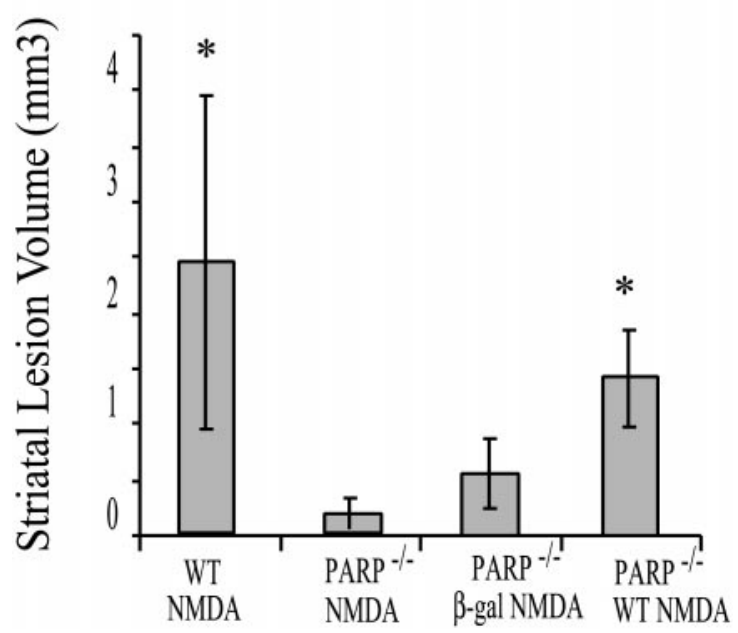

Figure 7. A, Coronal section through striatum $4 \mathrm{~d}$ after intrastriatal injection of Sindbis virus-expressing lacZ. Virus is prominent in part of the striatum. These results were replicated at least three times. $B$, Coronal section of a PARP-1 $1^{-/-}$mouse receiving Sindbis virus-expressing cDNA of WT PARP-1 and then $48 \mathrm{hr}$ after an intrastriatal injection of $20 \mathrm{nmol}$ of NMDA. The section is stained with cresyl violet and demonstrates a demarcated area of NMDA damage. $C$, Lesion volumes (mean \pm SD) of PARP-1 ${ }^{-1-}$ receiving Sindbis virus encoding PARP-1 WT cDNA $(n=3)$ demonstrate lesion volumes approaching that of WT mice receiving NMDA. PARP-1 ${ }^{-1-}$ mice receiving Sindbis virus only encoding lac $Z$ ( $n=$ 3) demonstrate significantly lower lesion volumes (significance determined by ANOVA with Newman-Keuls post hoc analysis; * $p<0.05$, significantly different from PARP-1 ${ }^{-1-}$ NMDA).

vates PARP-1. Our observations are consistent with previous studies indicating that $\mathrm{NO}$ and peroxynitrite play a prominent role in NMDA toxicity but little if any role in AMPA toxicity (Schulz et al., 1995b; Dawson and Dawson, 1996). The failure of NMDA to activate PARP-1 in nNOS ${ }^{-1-}$ animals is consistent with the preferential role of NO-peroxynitrite-mediated activation of PARP-1 in NMDA excitotoxicity. Furthermore, our findings are consistent with the results of cultures from PARP-1 $1^{-1-}$ mice that show dramatic resistance to NMDA- and NO-mediated toxicity (Eliasson et al., 1997). These findings confirm and extend these previous observations to the in vivo setting and also demonstrate that PARP-1 does not appear to play a prominent role in AMPA excitotoxicity.
Although PARP-1 plays a prominent role in NMDA-mediated excitotoxicity, it is not a key component to non-NMDA-mediated excitoxicity. Evidence of NMDA receptor coupling to nNOS through postsynaptic density 95 (Brenman et al., 1996; Sattler et al., 1999) is supportive of the proposed pathway leading from NMDA-R activation to PARP activation. NMDA activation is linked to production of NO via coupling to nNOS. Increased NO production when combined with superoxide anion results in peroxynitrite formation, a free radical species capable of DNA damage with resultant PARP activation. AMPA-R activation may lead to cell death through as yet undetermined effectors through interactions with glutamate receptor-interacting protein (Dong et al., 1997). This pathway does not appear to be dependent on peroxynitrite or PARP formation, suggesting initiation of neuronal death by events occurring outside the nucleus, but the identity of this pathway is not known.

A major concern in developing neuroprotective strategies is that the protection observed in animal studies may be short-lived. Previous studies investigating the role of PARP-1 in a variety of injury paradigms mainly focused on acute protection (Eliasson et al., 1997; Endres et al., 1997; Lo et al., 1998; Sun and Cheng, 1998; Szabo and Dawson, 1998; Takahashi and Greenberg, 1999; Takahashi et al., 1999). It may be argued that cell death was not prevented in these paradigms but merely delayed. To address this issue, we examined a cohort of animals to investigate chronic injury in which we assessed lesion volume 3 weeks after the intrastriatal NMDA lesion. Importantly, we do not observe a significant increase in lesion volume in the PARP-1 ${ }^{-1-}$ mice at 3 weeks, thus indicating that the protection observed is long-lasting. This has significant implications for the role of inhibition of PARP-1 as a potential therapeutic target in both acute and chronic neuronal injury. We demonstrate that PARP-1 inhibition appears to provide long-lasting neuroprotection, and previous studies show that even delayed administration of PARP-1 inhibitors can be neuroprotective (Zhang et al., 1994; Takahashi et al., 1999). Thus, PARP-1 inhibition may be an attractive neuroprotective target that provides long-lasting and effective treatment of acute injury even after the onset of injury.

The use of knock-out animals raises concerns that the observed phenotype may be attributable to the consequences of the absence of the gene during development or that the observed phenotype is actually attributable to compensatory processes rather than absence of the gene product. Specifically for this study, a concern may be raised that PARP $-1^{-1-}$ mice may have altered expression of NMDA receptors. However, Western blot analysis reveals similar expression of glutamate receptors in PARP- $1^{-1-}$ and WT cortical cultures and striatum. To address whether the resistance to NMDA in PARP-1 $1^{-1-}$ mice is directly attributable to the loss of PARP, we reintroduced wild-type PARP-1 into PARP-1 knock-out animals using recombinant replication-deficient Sindbis virus. Replicationdeficient Sindbis virus has been successfully used by other investigators to study proteins of interest in the nervous system because Sindbis virus expresses proteins at high levels and has a predilection for neurons (Lewis et al., 1996; Griffin, 1998; Gwag et al., 1998; Lundstrom, 1999). The replication-deficient Sindbis virus has been engineered to significantly attenuate Sindbis virus-mediated death (Gwag et al., 1998), and thus, it has minimal cytopathic effects. Sindbis virus-containing wild-type PARP-1 significantly restores the susceptibility to NMDA toxicity in PARP-1 ${ }^{-1-}$ mice, whereas Sindbis virus-containing $l a c Z$ fails to restore NMDA toxicity. Thus, the profound neuroprotection observed in PARP-1 ${ }^{-/-}$ mice to NMDA toxicity is attributable to the absence of the PARP-1 gene and not attributable to compensatory mechanisms.

Our investigations into the time course of PARP-1 activation reveal that NMDA elicits potent activation of PARP-1 within $2 \mathrm{hr}$ after intrastriatal injection of NMDA. This closely parallels the detection of peroxynitrite formation after NMDA intrastriatal injections as ascertained by nitrotyrosine immunostaining (Ayata et al., 1997). PARP-1 activation is maximal at $\sim 4 \mathrm{hr}$ and is still present $24 \mathrm{hr}$ after the initial NMDA lesion. This time course of 
PARP-1 activation is similar to that observed after middle cerebral artery occlusion, which is thought to be primarily an NMDA receptor-mediated excitotoxic event (Eliasson et al., 1997; Endres et al., 1997; Lo et al., 1998; Szabo and Dawson, 1998; Tokime et al., 1998). In addition, the time course is similar to that reported recently for MPTP-evoked dopaminergic neuronal death that is also thought to involve primarily an NO-excitotoxic pathway (Turski et al., 1991; Tabatabaei et al., 1992; Brouillet and Beal, 1993; Lange et al., 1993; Kanthasamy et al., 1997; Mandir et al., 1999).

Activation of PARP-1 plays a role in cell death in a variety of neurotoxic paradigms. There are several theories of how PARP-1 activation leads to neuronal death. One theory is that overactivation of PARP-1 leads to severe energy depletion and in turn to cell death. PARP-1 uses NAD as a substrate for ribosylation; replenishment of NAD levels depends on ATP consumption. Thus, ATP levels are depleted after neurotoxic insults that lead to PARP-1 activation, which could lead to energy compromise and neuronal death (Sims et al., 1983; Zhang et al., 1994; Berger et al., 1996; Tasker et al., 1998; Ha and Snyder, 1999). Our Western blot results for poly(ADP)ribosylation reveal multiple bands and suggest that proteins in addition to PARP are ribosylated after exposure to excitotoxic concentrations of NMDA. This observation raises an alternative possibility, that the ADP-ribosylation of a variety of target proteins may play a role in NMDA excitotoxicity. A number of potentially important nuclear proteins are ADP-ribosylated after activation of PARP-1, including histones, topoisomerase I, and p53 (Lautier et al., 1993; de Murcia et al., 1994). If the ribosylation of these target proteins plays a role in neurotoxicity, this could potentially account for the profound neuroprotection afforded by deletion of the PARP-1 gene. Alterations of any of these nuclear proteins may have a profound effect on cell survival, and their ribosylated products could be instrumental in initiating a cascade to cell death.

Yet another potential mechanism of PARP-1-mediated neuronal death is through its interaction with nuclear factor $-\kappa \mathrm{B}(\mathrm{NF}-\kappa \mathrm{B})$ (Oliver et al., 1999). PARP-1 ${ }^{-/-}$mice are resistant to endotoxic shock, which is attributable to the inability of lipopolysaccharide to activate $\mathrm{NF}-\kappa \mathrm{B}$ in PARP-1 $1^{-/-}$mice. It is conceivable that, after an inflammatory stress such as reperfusion after cerebral ischemia (Iadecola, 1997) or MPTP neurotoxicity (Liberatore et al., 1999), PARP-1 activation could lead to NF- $\kappa$ B activation, which in turn would contribute to the production of inflammatory mediators. Furthermore, recent experiments demonstrate downstream involvement of NF- $\kappa$ B to NMDA receptor activation in oxygen glucose deprivation experiments in tissue slices (Cardenas et al., 2000) and intrastriatal quinolinic acid inf usions (Nakai et al., 2000). $\mathrm{NF}-\kappa \mathrm{B}$ is activated after focal cerebral ischemia (Clemens et al., 1997; Gabriel et al., 1999; Schneider et al., 1999) and may have particular pertinence to the mechanisms of neuroprotection in PARP-1 ${ }^{-1-}$ mice.

PARP-1 activation has profound implications in neuronal death from excitotoxicity in acute and chronic central nervous system disorders. These results suggest a selective role of PARP-1 in glutamate excitotoxicity, and strategies of PARP-1 inhibition may offer acute and chronic neuroprotection.

\section{REFERENCES}

Affar EB, Duriez PJ, Shah RG, Sallmann FR, Bourassa S, Kupper JH, Burkle A, Poirier GG (1998) Immunodot blot method for the detection of poly (ADP-ribose) synthesized in vitro and in vivo. Anal Biochem 259:280-283.

Affar EB, Duriez PJ, Shah RG, Winstall E, Germain M, Boucher C, Bourassa S, Kirkland JB, Poirier GG (1999) Immunological determination and size characterization of poly(ADP- ribose) synthesized in vitro and in vivo. Biochim Biophys Acta 1428:137-146.

Ayata C, Ayata G, Hara H, Matthews RT, Beal MF, Ferrante RJ, Endres M, Kim A, Christie RH, Waeber C, Huang PL, Hyman BT, Moskowitz MA (1997) Mechanisms of reduced striatal NMDA excitotoxicity in type I nitric oxide synthase knock-out mice. J Neurosci 17:6908-6917.

Beckman JS, Crow JP (1993) Pathological implications of nitric oxide, superoxide and peroxynitrite formation. Biochem Soc Trans 21:330-334.

Berger NA (1985) Poly(ADP-ribose) in the cellular response to DNA damage. Radiat Res 101:4-15.
Berger R, Djuricic B, Jensen A, Hossmann KA, Paschen W (1996) Ontogenetic differences in energy metabolism and inhibition of protein synthesis in hippocampal slices during in vitro ischemia and $24 \mathrm{~h}$ of recovery. Brain Res Dev Brain Res 91:281-291.

Brenman JE, Christopherson KS, Craven SE, McGee AW, Bredt DS (1996) Cloning and characterization of postsynaptic density 93, a nitric oxide synthase interacting protein. J Neurosci 16:7407-7415.

Brouillet E, Beal MF (1993) NMDA antagonists partially protect against MPTP induced neurotoxicity in mice. NeuroReport 4:387-390.

Burkart V, Wang ZQ, Radons J, Heller B, Herceg Z, Stingl L, Wagner EF, Kolb H (1999) Mice lacking the poly(ADP-ribose) polymerase gene are resistant to pancreatic beta-cell destruction and diabetes development induced by streptozocin. Nat Med 5:314-319.

Cardenas A, Moro MA, Hurtado O, Leza JC, Lorenzo P, Castrillo A, Bodelon OG, Bosca L, Lizasoain I (2000) Implication of glutamate in the expression of inducible nitric oxide synthase after oxygen and glucose deprivation in rat forebrain slices. J Neurochem 74:2041-2048.

Choi DW (1988) Glutamate neurotoxicity and diseases of the nervous system. Neuron 1:623-634.

Clemens JA, Stephenson DT, Dixon EP, Smalstig EB, Mincy RE, Rash KS, Little SP (1997) Global cerebral ischemia activates nuclear factor-kappa B prior to evidence of DNA fragmentation. Brain Res Mol Brain Res 48:187-196.

D'Amours D, Desnoyers S, D'Silva I, Poirier GG (1999) Poly(ADPribosyl)ation reactions in the regulation of nuclear functions. Biochem $\mathrm{J}$ 342:249-268.

Dawson TM, Dawson VL, Snyder SH (1993) Nitric oxide as a mediator of neurotoxicity. NIDA Res Monogr 136:258-271.

Dawson VL, Dawson TM (1996) Nitric oxide neurotoxicity. J Chem Neuroanat 10:179-190.

Dawson VL, Dawson TM, London ED, Bredt DS, Snyder SH (1991) Nitric oxide mediates glutamate neurotoxicity in primary cortical cultures. Proc Natl Acad Sci USA 88:6368-6371.

Dawson VL, Dawson TM, Bartley DA, Uhl GR, Snyder SH (1993) Mechanisms of nitric oxide-mediated neurotoxicity in primary brain cultures. J Neurosci 13:2651-2661.

Dawson VL, Kizushi VM, Huang PL, Snyder SH, Dawson TM (1996) Resistance to neurotoxicity in cortical cultures from neuronal nitric oxide synthase deficient mice. J Neurosci 16:2479-2487.

de Murcia G, Schreiber V, Molinete M, Saulier B, Poch O, Masson M, Niedergang C, Menissier de Murcia J (1994) Structure and function of poly(ADP-ribose) polymerase. Mol Cell Biochem 138:15-24.

Dong H, O'Brien RJ, Fung ET, Lanahan AA, Worley PF, Huganir RL (1997) GRIP: a synaptic PDZ domain-containing protein that interacts with AMPA receptors. Nature 386:279-284.

Dubuisson J, Lustig S, Ruggli N, Akov Y, Rice CM (1997) Genetic determinants of Sindbis virus neuroinvasiveness. J Virol 71:2636-2646.

Eliasson MJ, Sampei K, Mandir AS, Hurn PD, Traystman RJ, Bao J, Pieper A, Wang ZQ, Dawson TM, Snyder SH, Dawson VL (1997) Poly(ADPribose) polymerase gene disruption renders mice resistant to cerebral ischemia. Nat Med 3:1089-1095.

Endres M, Wang ZQ, Namura S, Waeber C, Moskowitz MA (1997) Ischemic brain injury is mediated by the activation of poly(ADP-ribose)polymerase. J Cereb Blood Flow Metab 17:1143-1151.

Franklin KBJ, Paxinos G (1997) Mouse brain in stereotaxic coordinates. San Diego: Academic.

Gabriel C, Justicia C, Camins A, Planas AM (1999) Activation of nuclear factor-kappaB in the rat brain after transient focal ischemia. Brain Res Mol Brain Res 65:61-69.

Gonzalez-Zulueta M, Ensz LM, Mukhina G, Lebovitz RM, Zwacka RM, Engelhardt JF, Oberley LW, Dawson VL, Dawson TM (1998) Manganese superoxide dismutase protects nNOS neurons from NMDA and nitric oxide-mediated neurotoxicity. J Neurosci 18:2040-2055.

Griffin DE (1998) A review of alphavirus replication in neurons. Neurosci Biobehav Rev 22:721-723.

Gwag BJ, Kim EY, Ryu BR, Won SJ, Ko HW, Oh YJ, Cho YG, Ha SJ, Sung YC (1998) A neuron-specific gene transfer by a recombinant defective Sindbis virus. Brain Res Mol Brain Res 63:53-61.

Ha HC, Snyder SH (1999) Poly(ADP-ribose) polymerase is a mediator of necrotic cell death by ATP depletion. Proc Natl Acad Sci USA 96:13978-13982.

Huang PL, Dawson TM, Bredt DS, Snyder SH, Fishman MC (1993) Targeted disruption of the neuronal nitric oxide synthase gene. Cell 75:1273-1286.

Huang Z, Huang PL, Panahian N, Dalkara T, Fishman MC, Moskowitz MA (1994) Effects of cerebral ischemia in mice deficient in neuronal nitric oxide synthase. Science 265:1883-1885.

Iadecola C (1997) Bright and dark sides of nitric oxide in ischemic brain injury. Trends Neurosci 20:132-139.

Jackson AC, Moench TR, Trapp BD, Griffin DE (1988) Basis of neurovirulence in Sindbis virus encephalomyelitis of mice. Lab Invest 58:503-509.

Kanthasamy AG, Kanthasamy A, Matsumoto RR, Vu TQ, Truong DD (1997) Neuroprotective effects of the strychnine-insensitive glycine site NMDA antagonist (R)-HA-966 in an experimental model of Parkinson's disease. Brain Res 759:1-8.

Lange KW, Loschmann PA, Sofic E, Burg M, Horowski R, Kalveram KT, 
Wachtel H, Riederer P (1993) The competitive NMDA antagonist CPP protects substantia nigra neurons from MPTP-induced degeneration in primates. Naunyn Schmiedebergs Arch Pharmacol 348:586-592.

Lautier D, Lagueux J, Thibodeau J, Menard L, Poirier GG (1993) Molecular and biochemical features of poly(ADP-ribose) metabolism. Mol Cell Biochem 122:171-193.

Leist M, Nicotera P (1998) Apoptosis, excitotoxicity, and neuropathology. Exp Cell Res 239:183-201.

Lewis J, Wesselingh SL, Griffin DE, Hardwick JM (1996) Alphavirusinduced apoptosis in mouse brains correlates with neurovirulence. J Virol 70:1828-1835.

Liberatore GT, Jackson-Lewis V, Vukosavic S, Mandir AS, Vila M, McAuliffe WG, Dawson VL, Dawson TM, Przedborski S (1999) Inducible nitric oxide synthase stimulates dopaminergic neurodegeneration in the MPTP model of Parkinson disease. Nat Med 5:1403-1409.

Lipton SA, Rosenberg PA (1994) Excitatory amino acids as a final common pathway for neurologic disorders. N Engl J Med 330:613-622.

Lo EH, Bosque-Hamilton P, Meng W (1998) Inhibition of poly(ADPribose) polymerase: reduction of ischemic injury and attenuation of $N$-methyl-D-aspartate-induced neurotransmitter dysregulation. Stroke 29:830-836.

Lundstrom K (1999) Alphaviruses as tools in neurobiology and gene therapy. J Recept Signal Transduct Res 19:673-686.

Lynch DR, Dawson TM (1994) Secondary mechanisms in neuronal trauma. Curr Opin Neurol 7:510-516.

Mandir AS, Przedborski S, Jackson-Lewis V, Wang ZQ, SimbulanRosenthal CM, Smulson ME, Hoffman BE, Guastella DB, Dawson VL, Dawson TM (1999) Poly(ADP-ribose) polymerase activation mediates 1-methyl-4-phenyl-1, 2,3,6-tetrahydropyridine (MPTP)-induced parkinsonism. Proc Natl Acad Sci USA 96:5774-5779.

Masutani M, Suzuki H, Kamada N, Watanabe M, Ueda O, Nozaki T, Jishage K, Watanabe T, Sugimoto T, Nakagama H, Ochiya T, Sugimura T (1999) Poly(ADP-ribose) polymerase gene disruption conferred mice resistant to streptozotocin-induced diabetes. Proc Natl Acad Sci USA 96:2301-2304.

Meldrum B, Garthwaite J (1990) Excitatory amino acid neurotoxicity and neurodegenerative disease. Trends Pharmacol Sci 11:379-387.

Nakai M, Qin Z, Wang Y, Chase TN (2000) NMDA and non-NMDA receptor-stimulated IkappaB-alpha degradation: differential effects of the caspase-3 inhibitor DEVD.CHO, ethanol and free radical scavenger OPC-14117 Brain Res 859:207-216.

Oliver FJ, J Mn-dM, Nacci C, Decker P, Andriantsitohaina R, Muller S, de la Rubia G, Stoclet JC, de Murcia G (1999) Resistance to endotoxic shock as a consequence of defective NF-kappaB activation in poly (ADP-ribose) polymerase-1 deficient mice. EMBO J 18:4446-4454.

Olney JW (1990) Excitotoxicity: an overview. Can Dis Wkly Rep [Suppl 16] 1E:47-57.

Pieper AA, Brat DJ, Krug DK, Watkins CC, Gupta A, Blackshaw S, Verma A, Wang ZQ, Snyder SH (1999) Poly(ADP-ribose) polymerasedeficient mice are protected from streptozotocin-induced diabetes. Proc Natl Acad Sci USA 96:3059-3064.

Radons J, Heller B, Burkle A, Hartmann B, Rodriguez ML, Kroncke KD, Burkart V, Kolb H (1994) Nitric oxide toxicity in islet cells involves poly(ADP-ribose) polymerase activation and concomitant NAD + depletion. Biochem Biophys Res Commun 199:1270-1277.

Sattler R, Xiong Z, Lu WY, Hafner M, MacDonald JF, Tymianski M (1999) Specific coupling of NMDA receptor activation to nitric oxide neurotoxicity by PSD-95 protein. Science 284:1845-1848.

Schneider A, Martin-Villalba A, Weih F, Vogel J, Wirth T, Schwaninger M (1999) NF-kappaB is activated and promotes cell death in focal cerebral ischemia. Nat Med 5:554-559.
Schulz JB, Matthews RT, Beal MF (1995a) Role of nitric oxide in neurodegenerative diseases. Curr Opin Neurol 8:480-486.

Schulz JB, Matthews RT, Jenkins BG, Ferrante RJ, Siwek D, Henshaw DR, Cipolloni PB, Mecocci P, Kowall NW, Rosen BR (1995b) Blockade of neuronal nitric oxide synthase protects against excitotoxicity in vivo. J Neurosci 15:8419-8429.

Scott GS, Jakeman LB, Stokes BT, Szabo C (1999) Peroxynitrite production and activation of poly (adenosine diphosphate- ribose) synthetase in spinal cord injury. Ann Neurol 45:120-124.

Shah GM, Poirier D, Desnoyers S, Saint-Martin S, Hoflack JC, Rong P, ApSimon M, Kirkland JB, Poirier GG (1996) Complete inhibition of poly(ADP-ribose) polymerase activity prevents the recovery of C3H10T1/2 cells from oxidative stress. Biochim Biophys Acta 1312:1-7.

Sims JL, Berger SJ, Berger NA (1983) Poly(ADP-ribose) polymerase inhibitors preserve nicotinamide adenine dinucleotide and adenosine $5^{\prime}$ triphosphate pools in DNA-damaged cells: mechanism of stimulation of unscheduled DNA synthesis. Biochemistry 22:5188-5194.

Sun AY, Cheng JS (1998) Neuroprotective effects of poly (ADP-ribose) polymerase inhibitors in transient focal cerebral ischemia of rats. Chung Kuo Yao Li Hsueh Pao 19:104-108.

Szabo C, Dawson VL (1998) Role of poly(ADP-ribose) synthetase in inflammation and ischaemia- reperfusion. Trends Pharmacol Sci 19:287-298.

Tabatabaei A, Perry TL, Hansen S, Krieger C (1992) Partial protective effect of MK-801 on MPTP-induced reduction of striatal dopamine in mice. Neurosci Lett 141:192-194.

Takahashi K, Greenberg JH (1999) The effect of reperfusion on neuroprotection using an inhibitor of poly(ADP-ribose) polymerase. NeuroReport 10:2017-2022.

Takahashi K, Pieper AA, Croul SE, Zhang J, Snyder SH, Greenberg JH (1999) Post-treatment with an inhibitor of poly(ADP-ribose) polymerase attenuates cerebral damage in focal ischemia. Brain Res 829:46-54.

Tasker RC, Sahota SK, Cotter FE, Williams SR (1998) Early postischemic dantrolene-induced amelioration of poly(ADP-ribose) polymeraserelated bioenergetic failure in neonatal rat brain slices. J Cereb Blood Flow Metab 18:1346-1356.

Tokime T, Nozaki K, Sugino T, Kikuchi H, Hashimoto N, Ueda K (1998) Enhanced poly(ADP-ribosyl)ation after focal ischemia in rat brain. J Cereb Blood Flow Metab 18:991-997.

Turski L, Bressler K, Rettig KJ, Loschmann PA, Wachtel H (1991) Protection of substantia nigra from MPP + neurotoxicity by $N$-methyl-Daspartate antagonists. Nature 349:414-418.

Wang ZQ, Stingl L, Morrison C, Jantsch M, Los M, Schulze-Osthoff K, Wagner EF (1997) PARP is important for genomic stability but dispensable in apoptosis. Genes Dev 11:2347-2358.

Weiss SW, Albers DS, Iadarola MJ, Dawson TM, Dawson VL, Standaert DG (1998) NMDAR1 glutamate receptor subunit isoforms in neostriatal, neocortical, and hippocampal nitric oxide synthase neurons. J Neurosci 18:1725-1734.

Xia Y, Dawson VL, Dawson TM, Snyder SH, Zweier JL (1996) Nitric oxide synthase generates superoxide and nitric oxide in arginine-depleted cells leading to peroxynitrite-mediated cellular injury. Proc Natl Acad Sci USA 93:6770-6774.

Zhang J, Pieper A, Snyder SH (1995) Poly(ADP-ribose) synthetase activation: an early indicator of neurotoxic DNA damage. J Neurochem 65:1411-1414

Zhang J, Dawson VL, Dawson TM, Snyder SH (1994) Nitric oxide activation of poly(ADP-ribose) synthetase in neurotoxicity. Science 263:687689. 